\title{
The cytotoxic and apoptotic effects of wild and polyploidy genotype of Artemisia cina extracts on the WiDr colon and HTB-183 lung cancer cell lines
}

\author{
ELIZABETH BETTY ELOK KRISTIANI ${ }^{1,2, v}$, SRI KASMIYATI ${ }^{1, v \vee}$, MARIA MARINA HERAWATI $^{2}$ \\ ${ }^{1}$ Department of Biology, Faculty of Biology, Universitas Kristen Satya Wacana. Jl. Diponegoro 52-60, Salatiga 50711, Central Java, Indonesia. \\ Tel./fax.: +62-298-321212, ‘email: betty.elok@uksw.edu, “»email: kas@uksw.edu \\ ${ }^{2}$ Department of Agronomy, Faculty of Agricultural and Bussiness, Universitas Kristen Satya Wacana. Jl. Diponegoro 52-60, Salatiga 50711, Central \\ Java, Indonesia
}

Manuscript received: 22 December 2020. Revision accepted: 23 June 2021.

\begin{abstract}
Kristiani EBE, Kasmiyati S, Herawati MM. 2021. The cytotoxic and apoptotic effects of wild and polyploidy genotype of Artemisia cina extracts on the WiDr colon and HTB-183 lung cancer cell lines. Biodiversitas 22: 2844-2852. Artemisia belongs to the Asteraceae family, usually used for traditional treatments of various diseases in China. Artemisia cina Berg ex Poljakov, which lots found in Indonesia, has not been studied much like a cancer drug. The research aims were (i) to compare the bioactive content of hexane and ethyl acetate extract of wild (TWN and KJT) and polyploidy type ( $\mathrm{J}$ and $\mathrm{M}$ ) of A. cina and its cytotoxicity on WiDr and HTB-183 cancer cells, (ii) to evaluate the cytotoxicity mechanism of the most substantial extract of it. All of the extracts were prepared by maceration methods using hexane and ethyl acetate separately. The research method used was quantitative with experimental design. The determination of quercetin, kaempferol, and artemisinin used HPLC. The cytotoxicity of the extract determined using the MTT method. The assay of the specific protein related to apoptosis using ICC assay. The content of three bioactive compounds on ethyl acetate extracts higher than hexane extract, in which the extract of $\mathrm{J}$ and KJT genotypes had higher levels than M and TWN genotypes. The IC50 value $(\mu \mathrm{g} / \mathrm{mL})$ of extracts against cancer cell lines tested was about 400-700 hexane extracts and 200-500 ethyl acetate extracts. The BCl-2 expressions of both cancer cell lines decreased by treating TWN-EA and M-EA, while the P53 expressions increased. The TWN-EA induced apoptosis of HTB-183 cell lines through caspase-8 and caspase-9 pathways, but M-EA induced caspase-9 pathway only. The TWN and M genotypes were potential to use as anticancer agents on colon and lung cancer.
\end{abstract}

Keywords: Artemisia cina, apoptosis, Bcl-2, caspase, cancer, cytotoxicity, p53

Abbreviations: B2P2TOOT: Balai Penelitian dan Pengembangan Tanaman Obat dan Obat Terstandar; MTT: 3-[4,5-dimethylthiazole-2yl]-2,5-diphenyltetrazolium bromide; ICC: Immunocytochemistry, HPLC: High-Pressure Liquid Chromatography, TWN-EA: ethyl acetate extract of TWN; M-EA: ethyl acetate extract of M

\section{INTRODUCTION}

According to World Health Organization (WHO), cancer is one of the leading causes of death worldwide, with around 9.6 million deaths in 2018. From that, lung cancer is the first (2.09 million cases), and colon cancer is the third (1.80 million cases) cause (WHO 2018). Colorectal cancer (CRC) becomes the third cause of death by cancer cases in the United States of Amerika. National Center for Health Statistics reported that in 2020, it is about 147,950 CRC cases, and 40\% died (Siegel et al. 2020). About lung cancer, this cancer as the most leading of death caused by cancer in China in recent years (Cheng et al. 2020).

Cancer treatments that are primarily carried out include surgery, radiation and chemotherapy, which are very high so that it is a burden to the patient concerned or the country and still causes side effects (Abdullah et al. 2014). It encourages exploring new drugs by using the natural material approach that has traditionally been used as medicine (ethnobotanical bioprospecting approach) (Kashani et al. 2012). Many countries had an endemic plant usually used as medicinal plants, such as Albertisia papuana Becc. and others in Indonesia (Kristiani et al. 2016; Sholikhah 2016). Heracleum platytaenium and others in form Turkey (Tuzlaci and Senkardes 2011; Akillilar et al. 2018), in China, included A. capillaries Thunb, A. centifolia Buch-Ham. Ex Roxb, A. japonica Thunb, etc. (Gao et al. 2019). The pharmacological ability of herbal medicines is influenced by their bioactive compounds, which are usually secondary metabolites (Kashani et al. 2012). The type of bioactive compound carried in an extract is closely related to the solvent used to extract the sample (Dai and Mumper 2010). Most of the techniques are based on the kind of solvent, the time of mixing, and the temperature of the process (Naboulsi et al. 2018; Zhang et al. 2018). Solvent determination is very crucial in the extraction process. Several properties such as selectivity, solubility, cost and safety are considered when selecting solvents. The likes to dissolve like principle describes the polarity of the solvent will affect the polarity of the extracted compound (Zhang et al. 2018). A study of Severinia buxifolia (Rutaceae) showed that the influence of the used solvent on the many essential roles included the 
yield of extraction, the content of bioactive components, and biological activities. The kind of solvent used was distilled water $\left(\mathrm{H}_{2} \mathrm{O}\right), \mathrm{MeOH}$, EtOH, $\mathrm{CHCl}_{3}, \mathrm{CH}_{2} \mathrm{Cl}_{2}$, and $\mathrm{Me}_{2} \mathrm{CO}$ (Zhang et al. 2018). Ngo et al. (2017) used seven solvents with different polarity indexes are 10.2, 5.1, 4.3, and 5.1, respectively, to extract the bioactive compounds from Salacia chinensis L. root. It shown that acetone $(50 \%$ v/v) was found to be the optimal extraction solvent for extractable solids $50 \%$ acetone is recommended for the extraction of phenolic compounds, their secondary metabolites, saponins, and antioxidant capacity from the root of $S$. chinensis for further isolation and utilization.

Based on their structure, they are divide into three groups that are terpenes and compounds contained N/S and phenolics compounds. (Pagare et al. 2015). Flavanoids are a member of the phenolic compound group with a wide range of function in the plant. The type of secondary metabolite compounds can be extracted using extraction techniques. Many secondary metabolites were shown to include polyphenolic compounds, including flavonoids, tannins, curcumin, resveratrol and gallocatechin, and brassinosteroids (Greenwell and Rahman 2015). Shree et al. (2019) represented that terpenoids, flavonoids, phenols and alkaloids were compounds that could be anticancer agents. Wang et al. (2012) stated that there are various anticancer compounds, including kaempferol and triterpenoids.

In the last decade, various research results have shown that certain compounds in plants exhibit cytotoxic activity against cancer cells so that they can be used as a source to obtain new cancer drugs (Arullappan et al. 2013). Artemisia belongs to the Asteraceae family, which usually used as medicine. Artemisia annua has long used in China for traditional treatments of various diseases. Previous studies have shown that these bioactive compounds in Artemisia have antimicrobial, antimalarial, antioxidant, anthelmintic, and anticancer effects (Koul et al. 2017; Kasmiyati et al. 2020). Kursat et al. (2015) was identified that the quercetin and kaempferol content in five types of Artemisia was similar to A. spicigera and A. splendens. They were found that the two compound. Both compounds were not found in A. haussknechtii Boiss. The quercetin content in A. armeniaca Lam., A. Incana (L.) Druce, A.tournefortiana Reichb., and A. scoparia Waldst. \& Kit was about $0.001-0.065 \%$, while the kaempferol content was about $0.003-0.02 \%$ in A. Armeniaca Lam, A. tournefortiana Reich, and A. scoparia Waldst. \& Kit only. Identification of $A$. absinthium leaf by Lee et al. (2003) showed that the content of quercetin and kaemferol were low too, that was $0.0031 \%$ and $0.0013 \%$, respectively. The artemisinin concentration on Artemisia was influenced by altitude and soil (Mukazayire et al. 2009). They were found that artemisinin content on A. апnиа was grown at higher $2000 \mathrm{~m}, 1800 \mathrm{~m}$, and $1650 \mathrm{~m}$ were $1.11 \%, 1.17 \%$ and $0.46 \%$, respectively. The content of artemisinin varied in every part of the plant to flowers, leaves, stems, and roots. Those reports informed the possibility of Artemisia as an anticancer agent.

The phytopharmaceutical compounds of Artemisia are very potential, but are small. Tetraploid induction of this plant increased the secondary metabolites content of plants (Carusoa et al. 2013). The artemisinin content of this species very little is about $0,0075-0,66 \%$. Tetraploid induction of this plant increased the artemisinin content three times than the diploid plant (Herawati et al. 2003). The increased levels of artemisinin may allow changes in the level of other secondary metabolites. The increase of bioactive compounds will affect its cytotoxic capability, and thus, this research will measure the anticancer bioactive compounds of the wild and polyploidy type of Artemisia cina Berg ex Polyakov. The previous research has shown that out of the four cancer cells observed, the toxicity level of this plant against colon cancer cell WiDr, and lung cancer cell HTB-183, is more substantial than it is against breast cancer cells $\mathrm{T} 47 \mathrm{D}$ and cervix cancer cell HeLa. Because the ability to modulate a cell's life and death is the most sought-after potential in anticancer studies, cell cycle and apoptosis mainly focus on those studies (Elmore 2007).

Based on that, the research aims were (i) to compare the cytotoxicity and bioactive content of hexane and ethyl acetate extract of wild and polyploidy type of $A$. cina on WiDr and HTB-183 cancer cells and (ii) to evaluate the cytotoxicity mechanism of the most substantial extract of it.

\section{MATERIALS AND METHODS}

\section{Materials}

The method of research used was quantitative with experimental design. There were two kinds of genotypes of Artemisia cina used that was the wild type and polyploidy mutant. Two kinds of wild types genotypes were including TWN and KJT. TWN was a diploid genotype plant derived from the Center for Research and Development of Medicinal Plants and Traditional Medicine (B2P2TOOT) Tawangmangu, Centre of Java, Indonesia, directly grown Saharan greenhouse. KJT was a diploid genotype tissue culture with no induction. $\mathrm{J}$ and $\mathrm{M}$ were polyploid genotypes. J obtained by inducing $A$. cina to shoot culture with two $\mathrm{mg} / \mathrm{l}$ of $2.4 \mathrm{D}$ and three $\mathrm{mg} / \mathrm{l}$ of IBA for 21 days, while $\mathrm{M}$ obtained by two $\mathrm{mg} / \mathrm{l}$ of $2.4 \mathrm{D}$ and $1.5 \mathrm{mg} / \mathrm{l}$ of IBA for 21 days (M). The A. cina plant collection (No. 001 until No. 004/2014/FPBUKSW/Koleksi) was preserved in the laboratory of the Faculty of Agricultural and Bussiness, Satya Wacana Christian University, Salatiga, Indonesia. The WiDr and HTB-183 cancer cell lines were obtained from Parasitology Laboratory, Faculty of Medicine, Universitas Gadjah Mada, Yogyakarta, Indonesia.

\section{Preparation of extract}

The whole part of the plant was air-dried, followed by counting using a blender (Philip HR1538). The extracts were prepared using hexane and ethyl acetate as the solvent, separately and accompanied by stir using the magnetic stirrer. The maceration process was repeated five times. Every process was carried out for about three hours, and the filtrate was filtered using filter paper. The combined filtrate was dried using a rotary evaporator 
(Rotavapor R114 Buchi) under vacuum (Eyela A-1000S) at $40^{\circ} \mathrm{C}$.

\section{Determination of bioactive compounds using HPLC Quercetin and kaempferol (Tokuşoğlu et al. 2003 with a slight modification)}

The sample is converted into flavonoid glycosides form, and then the glycosides are hydrolyzed to form an aglycon flavonoid before being injected into the HPLC. Samples were added with methanol containing $1 \% \mathrm{HCl}(1$ : $1 \mathrm{w} / \mathrm{v}$ ) and sonicated (SonicatorKrisbow DSA50-GL2$2,5 \mathrm{~L}$ ) for 30 minutes. The mixture filtered; part of the filtrate is taken (as a glycoside flavonoid extract) hydrolyzed. The glycoside flavonoid extract was saturated to a particular volume and added with $1.2 \mathrm{M} \mathrm{HCl}$ as much as $20 \%$ of the volume of the extract's fulfillment, then refluxed at $90^{\circ} \mathrm{C}$ for 2 hours. After the extract cooled, sonication was continued for 3 minutes and then filtered using a $0.45 \mu \mathrm{m}$ filter membrane. The filtrate obtained is an aglycon flavonoid and is ready to be injected into HPLC (Knauer Germany Series Smartline). The modifications of operational conditions of the HPLC include use of Chromosorb RP C18 (150x5 mm id) Knauer as a column, $0.1 \% \mathrm{H}_{3} \mathrm{PO}_{4}$ acetonitrile (60:40) as mobile phase with flow rate was $1 \mathrm{~mL} / \mathrm{mnt}$, an ambient temperature, and UV 370 $\mathrm{nm}$ as a detector. The volume of injection was $20 \mu \mathrm{L}$ : pure quercetin, and pure kaempferol used as standard compounds.

\section{Artemisinin (Numonov et al. 2019 with modification)}

The $100 \mathrm{mg}$ powdered sample was added with $100 \mathrm{mg}$ granular quartz and $2 \mathrm{~mL}$ toluene and then crushed using mortar. The filtrate was filtered and stored in a container. The $500 \mu \mathrm{L}$ filtrate was evaporated to dryness and then redissolved using $200 \mu \mathrm{L}$ methanol and $800 \mu \mathrm{L} \mathrm{NaOH} 0.2$ $\%$ w/v. The solution was agitated using a vortex mixer (Scilogex Type MX-S)) and then heated using a water bath (Memert) in $50^{\circ} \mathrm{C}$ for 30 minutes and cooled again. After this, the solution was homogenized with $200 \mu \mathrm{L}$ methanol and $800 \mu \mathrm{L}$ acetic acid and then filtered using a $0.45 \mu \mathrm{m}$ membrane filter. The filtrate in the form of artemisinin was ready to be injected into the HPLC. The modification of HPLC conditions was included the Chromosorb column RP C18 (150x5 mm id), Knauer, the mobile phase was buffer Phosphate 0,01 M pH7: methanol (55:45), the flow rate was $0.5 \mathrm{~mL} / \mathrm{min}$, the volume of injection was $20 \mu \mathrm{L}$, ambient temperature, and using UV $260 \mathrm{~nm}$ detector. The pire artemisinin was used as standard compounds.

\section{Cytotoxic assay}

The cytotoxicity limit of the extract determined using the MTT method adapted from (Arullappan et al. 2013) with a slight modification. The modifications were about using SDS as a stopper of the formation of formazan crystals and the time of the incubation process done overnight. The $100 \mu \mathrm{L}$ of cells with a density of $1 \times 104$ cells/wells put into a 96 -well microplate and incubated in a $5 \% \mathrm{CO}_{2}$ incubator at $37^{\circ} \mathrm{C}$ for 24 hours. The plate is passed out from the incubator, and the medium was discarded. The plate was re-incubated in a 5\% $\mathrm{CO} 2$ incubator at $37^{\circ} \mathrm{C}$ for 24 hours. The absorbance of each well was read on an ELISA reader at a wavelength of $595 \mathrm{~nm}$. The conversion of absorbance to the percentage of living cells (cell viability) using the formula:

Viability cell $(\%)=(($ Measured absorbance - medium absorbance) / (cell absorbance - medium absorbance)) $\mathrm{x}$ $100 \%$.

\section{Immunocytochemistry assay}

The ICC assay was used to assay the specific protein related to apoptosis. In this study, they were $\mathrm{BCl}-2$, P53, caspase eight and caspase nine protein. The immunocytochemical method refers to (Susidarti et al. 2014) with slight modifications. Two modifications in the cell incubation after treatment were for 24 hours, and in the use of emersion, the liquid was use entelan.

\section{Data analysis}

The $\mathrm{IC}_{50}$ values of every sample were calculated using SPSS 16 (Probit/Logit). The differences of $\mathrm{IC}_{50}$ values and content of bioactive compounds between each extract were analyzed statistically by analyzing variance (ANOVA) using the SAS ver. 9.1.3. If there is a significant effect of treatment with control, the test is continued with the Tukey test at a test level of 5\%. All experiments conducted in five replicates.

\section{RESULTS AND DISCUSSION}

\section{Content of bioactive compounds}

In this study, the bioactive compounds analyzed were quercetin and kaempferol as a member of the phenolic group and artemisinin as a member of the terpene group of secondary metabolites (Figure 1.). The determination of bioactive compounds using HPLC. HPLC is a chromatographic technique that can be used to identify, measure and purify the individual components (Piana et al. 2013). We used this technique because of its versatility for estimating secondary metabolites in plants (Boligon and Athayde 2014) with the advantages of a fast, sensitive, and accurate analysis process (Martin et al. 2005, Mahendra et al. 2011). In all types of $A$. china analyzed, the content of the three bioactive compounds in the ethyl acetate extracts was higher than the hexane extract. The two highest levels of the three compounds were ethyl acetate extract of $\mathbf{J}$ and KJT genotypes that were quercetin at about $0.40-0.55$, kaemferol $0.50-0.60$, artemisinin 12.0-14.0 $\mu \mathrm{g} / \mathrm{mL}$ of extract. The ethyl acetate extract of $\mathrm{M}$ and TWN genotypes had lower levels than $\mathrm{J}$ and KJT genotypes: quercetin at about 0.25-0.35, kaemferol 0.50-0.60 artemisinin 3.35-4.45 $\mu \mathrm{g} / \mathrm{mL}$ of extract.

The ethyl acetate extract contained the three bioactive compounds measured were significantly higher than hexane extract, both in wild or polyploid genotype. The highest content was in the KJT and J genotypes and then TWN and M. 

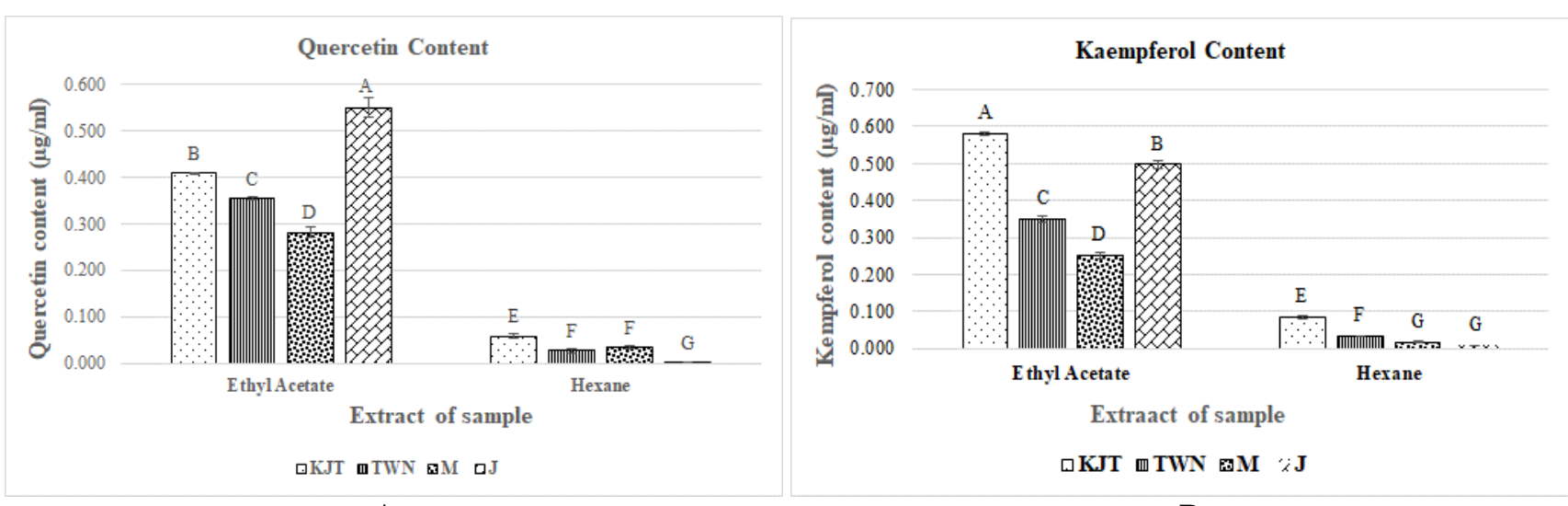

A B

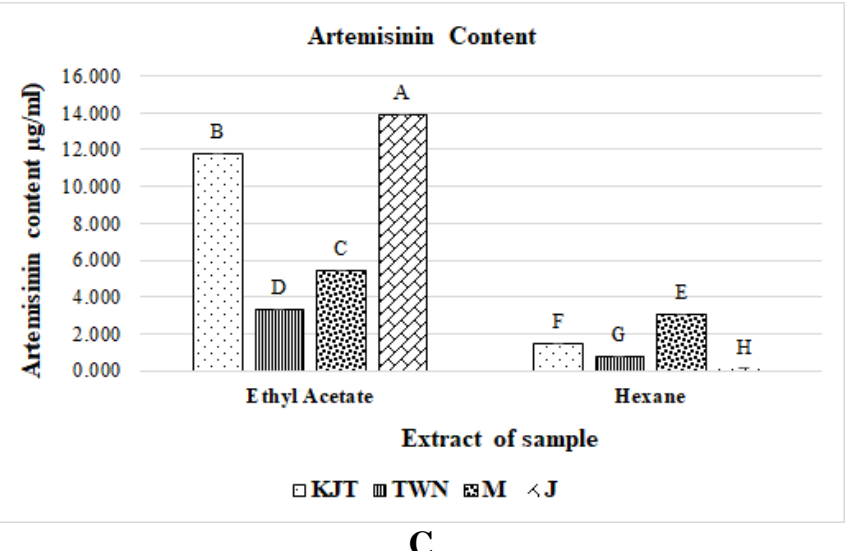

Figure 1. The bioactive content of hexane and ethyl acetate extract of wild and polyploidy type of Artemisia cina. A. Quercetin content; B. Kaempferol content; C. Artemisinin content. Note: The value represents the mean $(n=3)$; All mean values were analyzed using oneway ANOVA and followed by the Duncan test to compare the mean difference between samples ( $p>0.05)$. The different letters showed significantly different value

\section{Cytotoxic assay}

The MTT assay is based on the conversion of MTT into formazan crystals by living cells. It is identical to the activity of mitochondrial. The mitochondrial activity of cell populations is related to the number of viable cells, so this assay is used to measure anticancer agents' in vitro cytotoxic effects on cell lines (Meerloo et al. 2011). The cytotoxicity of all extracts expressed as $\mathrm{IC}_{50}$ value. All of the extracts showed the $\mathrm{IC}_{50}$ value was more than 200 $\mu \mathrm{g} / \mathrm{mL}$ on both cancer cells tested (Table 1.). The $\mathrm{IC}_{50}$ value of hexane extracts on WiDr colon cancer cell lines was about $400 \mu \mathrm{g} / \mathrm{mL}$ (KJT and J) and $600 \mu \mathrm{g} / \mathrm{mL}$ (TWN and M) HTB 183. They were around 500-700 $\mu \mathrm{g} / \mathrm{mL}$. On about ethyl acetate extract, based on the $\mathrm{IC}_{50}$ value on both cancer cell lines, the ethyl acetate extracts of TWN and M (200-300 $\mu \mathrm{g} / \mathrm{mL})$ were more toxic than hexane extracts, while KJT and J extract were not (300-500 $\mu \mathrm{g} / \mathrm{mL})$.

It appears that the ethyl acetate extract of the TWN and $\mathrm{M}$ genotypes can inhibit cancer cell growth more substantially than the others. Both extracts showed $\mathrm{IC}_{50}$ value was about $300 \mu \mathrm{g} / \mathrm{mL}$, while other extracts had $\mathrm{IC}_{50}$ more than this, even until about $700 \mu \mathrm{g} / \mathrm{mL}$.

\section{Immunocytochemistry assay}

Immunocytochemistry is a very productive method to identify specific proteins in tissues and cells - the method usually used in biomedical research. To show the location of the test protein correctly and consistently, a control is used as a comparison (Poojan et al. 2018)). This study determined the protein expression related to cell apoptosis that was $\mathrm{BCl}-2 \mathrm{p} 53$, caspase- 8 , and caspase- 9 . Based on the trend in Figure 1, the assay of a marker protein of apoptosis performed on both the extract. As can be seen, M and TWN extracts induced more potent antiproliferative effects in WiDr and HTB-183 cell lines and induced the caspase enzyme activity (Fig. $1-3$ ).

\section{Discussion}

Herbal medicinal are usually used as sources of agents for traditional medicines for thousands of years. In recent years, natural products and their derivate became beneficial alternative therapy (Akillilar et al. 2018). Artemisia is one of the well-known plants for its antimicrobial, insecticidal, antioxidant, and antimalarial ability. At first, this plant was widely known for its ability to treat malaria, with the bioactive compound artemisinin, but recently the ability of the Artemisia plant as an anticancer agent has been widely studied. Many studies have shown that these bioactive compounds in Artemisia have antimicrobial, antimalarial, antioxidant, anthelmintic and anticancer effects (Hussain et al. 2017). This study was designed to compare the genotype of diploid and polyploidy of A. cina in inhibiting the growth of cancer cells WiDr and HTB-183 through cytotoxicity assay by the MTT methods and mechanisms of apoptosis induction by the ICC assay. 
Table 1. The cytotoxicity of Artemisia cina extracts on the cancer cell lines

\begin{tabular}{|c|c|c|c|c|}
\hline \multirow{3}{*}{$\begin{array}{l}\text { Genotype/ } \\
\text { Extract }\end{array}$} & \multicolumn{4}{|c|}{ The IC 50 value of extract on the cancer cell line $(\mu \mathrm{g} / \mathrm{mL})$} \\
\hline & \multicolumn{2}{|c|}{ WiDr colon cancer } & \multicolumn{2}{|c|}{ HTB-183 lung cancer } \\
\hline & Hexane & Ethyl acetate & Hexane & Ethyl acetate \\
\hline TWIN & $679.6 \pm 45.1 \mathrm{AB}$ & $292.3 \pm 4.0 \mathrm{E}$ & $747.2 \pm 111.5 \mathrm{AB}$ & $298.5 \pm 34.5 \mathrm{E}$ \\
\hline KJT & $481.8 \pm 43.6 \mathrm{CD}$ & $434.0 \pm 30.1 \mathrm{D}$ & $556.3 \pm 93.3 \mathrm{C}$ & $505.7 \pm 91.2 \mathrm{CD}$ \\
\hline $\mathrm{J}$ & $434.6 \pm 102.9 \mathrm{D}$ & $325.2 \pm 9.9 \mathrm{E}$ & $654.4 \pm 22.6 \mathrm{~B}$ & $471.7 \pm 34.1 \mathrm{CD}$ \\
\hline M & $662.1 \pm 9.6 \mathrm{~B}$ & $229.5 \pm 19.9 \mathrm{E}$ & $768.4 \pm 38.0 \mathrm{~A}$ & $317.2 \pm 23.4 \mathrm{E}$ \\
\hline
\end{tabular}

Note: The value represents the mean \pm standard deviation (SD) $(n=3)$; Mean values in the same column and row having different letters differ significantly were analyzed using one-way ANOVA and followed by the Duncan test to compare the mean difference between samples $(\mathrm{p}>0.05)$

In this study, each genotype extracted with two kinds of solvent was hexane and ethyl acetate. The polarity of ethyl acetate $(0.228$; medium polarity) is higher than hexane (0.009; a-polar). The phytochemical ability of an extract depends on the bioactive compounds in an extract. The type of bioactive compound carried in an extract is closely related to the solvent used to extract the sample (Dai and Mumper 2010). It means that hexane and ethyl acetate will extract the different bioactive compounds of extract, giving the different cytotoxicity on both cancer cell lines. It is seen in the results of this study, the levels of the compounds assayed were different between both extracts. The content of the compounds in ethyl acetate extract was higher than that of hexane extract. It resulted in different cytotoxic strengths of the extract. Based on the result of statistical analysis of $\mathrm{IC}_{50}$ value (Table 1), in general, the results showed the cytotoxic activity of the ethyl acetate extract was more potent than hexane extract on both cancer cell lines, WiDr and HTB-183. Among these, the best antiproliferative ability against the two cancer cells tested was ethyl acetate extract of TWN and M genotype. For the action mechanism study, we used both extracts. Like this result, the antiproliferative ability of several types of Artemisia extracted with various types of solvents including n-hexane, $\mathrm{Me}-\mathrm{OH}, \mathrm{CH}_{2} \mathrm{Cl}_{2}$, and EtO-Ac against various cancer cell line (AGS human gastric adenocarcinoma, HT-29 human colon adenocarcinoma, MCF-7 human breast carcinoma, L929 mouse fibroblast) was varied. The types of Artemisia were A. diffusa, A. santolina, A. ciniformis, A. annua, A. biennis, A. persica, dan A. vulgaris (Rabe et al. 2011). A study on the A. Armeniaca showed that the cytotoxic activity of $\mathrm{MeOH}$ extracts and fractions and fractions of n-hexane, $\mathrm{CH}_{2} \mathrm{Cl}_{2}$, EtOAc, n-BuOH and $\mathrm{H}_{2} \mathrm{O}$ on normal K562, HL-60 and J774 cell growth were dose-dependent (Mojarraba et al. 2013). The $\mathrm{CH}_{2} \mathrm{Cl}_{2}$ and petroleum ether extracts of $A$. ciniformis showed higher cytotoxic on HL-60 and K562 cancer cell lines than EtOAc, EtOH EtOH-water extracts, with $\mathrm{IC}_{50}$ value at around $25 \mu \mathrm{g} / \mathrm{mL}$ (Tayarani-Najaran et al. 2014).

The anticancer ability is due to the nature of carcinogenic compounds, both chemical and radiation, which inhibit growth and induce cell death or mediate a common apoptotic pathway. There are several steps to obtain the bioactive compounds from the plant, including drying, grinding, and extraction, and among them, extraction becomes the critical step (Do et al. 2014). One of the influence factors in extraction is solvent (Truong et al. 2019; Zhang et al. 2018). This study used hexane and ethyl acetate as a solvent to take the bioactive content in both polyploidy and wild type of $A$. cina. The three compounds widely recognized as bioactive anticancer agents are quercetin and kaempferol, secondary metabolites of the flavonoid class, and artemisinin is a terpene group. In their review article, Hussain et al. (2017) stated that besides artemisinin, flavonoids, steroids, glycosides, terpenoids, caffeoylquinic acids, acetylenes, coumarins and sterols were also found in Asteraceae. Flavonoids have been demonstrated to have cytotoxic activities toward numerous human cancer cells, whereas they have little or no effect on normal cells (Yuan et al. 2016). Study on ethyl acetate extract of $A$. vulgaris L. and A. alba Turra showed that antiproliferative activities increased with time exposure. Both extracts contained phenolic compounds and flavonoids (Jakovljević et al. 2019). The dichloromethane fraction of ethanol eluate of $A$. sacrorum Ledeb showed the most vigorous cytotoxic activities on HepG2, HT-29, and

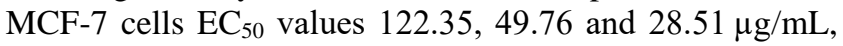
respectively. One of the compounds of was flavonoid (Piao et al. 2012). The methanol extracts of eight Artemisia species showed the most substantial antiproliferative effect on MCF-7 cells and induced apoptosis via an ER-related pathway at $200 \mathrm{ppm}$. These eight species were $A$. stolonifera, A. selengensis, A. japonica, A. Montana, A. capillaris, A. sylvatica, A. keiskeana, and A. scoparia (Choi and Kim 2013). In the study, ethyl acetate extracts of TWN and $\mathrm{M}$ contained quercetin, kaempferol, and artemisinin smaller than KJT and J, but their cytotoxic ability against the two cancer cell lines was more remarkable. The three compounds may cause cytotoxic ability, but there are other compounds that we did not measure in this study. Jakovljević et al. (2019) reported that an ethyl acetate extract of $A$. vulgaris and A. alba, which showed the antiproliferative activities, contained phenolic compounds that included phenolic acids (gallic, p-coumaric, vanillic, and ferulic acids), beside flavonoids included rutin, myricetin, luteolin, quercetin, and apigenin. Wang et al. (2012) stated that there are various anticancer compounds, including kaempferol and triterpenoids. 


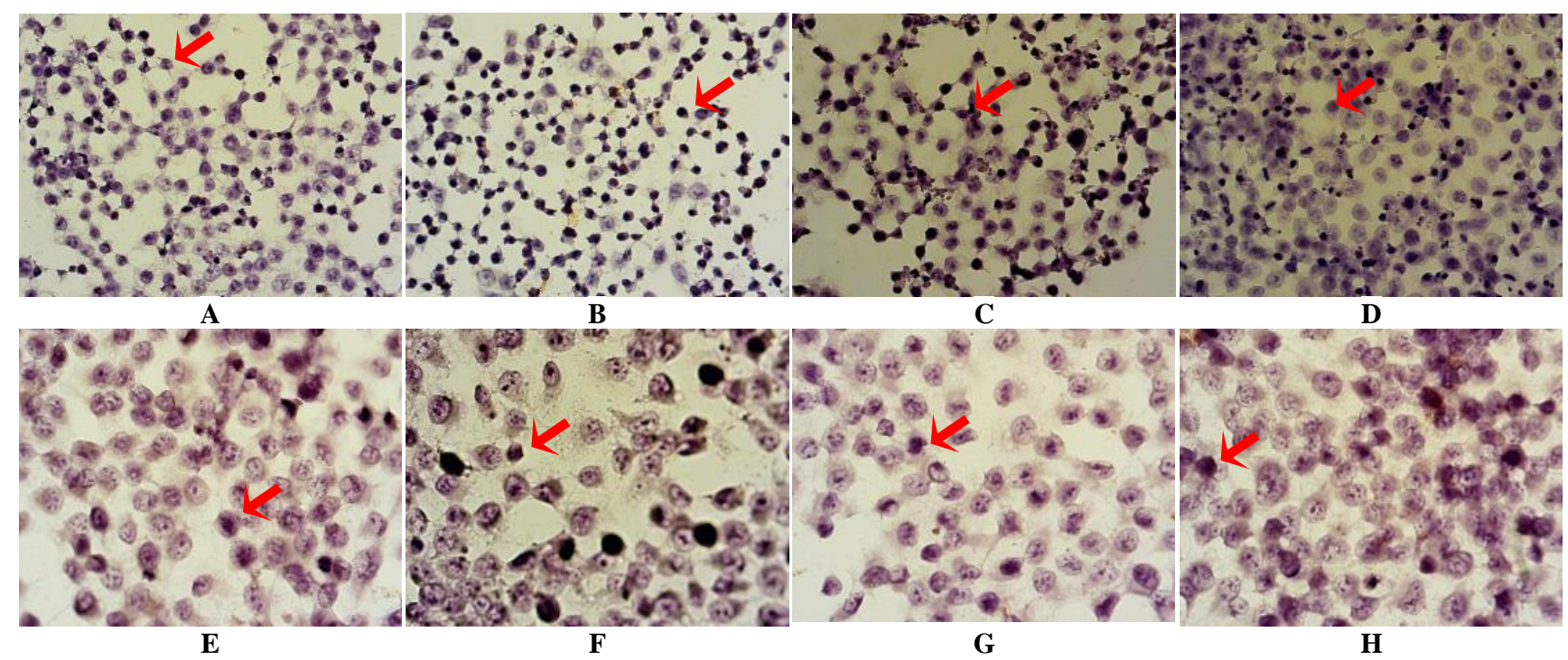

Figure 1. The histology appearance of WiDr and HTB-183 cancer cell line using a light microscope at 400x magnification by treating extract of diploid (TWN) and polyploidy (M) of Artemisia cina on apoptosis proteins included Bcl-2, p53, caspase-8, and caspase-9. A. WiDr cell on Bcl-2 expression without treatment; B. WiDr cell on p53 expression with M extract treatment; C. WiDr cell on caspase-8 expression with TWN extract treatment; D. WiDr cell on caspase-9 expression with M extract treatment. E. HTB-183 on Bcl-2 expression without treatment; F. HTB-183 on p53 expression with M extract treatment; G. HTB-183 cell on caspase-8 expression with M extract treatment; H. HTB-183 cell on caspase-9 expression without treatment. Note: The red arrow represents the positive assay.

The excellence of therapeutic to modulate cell life or death is the most sought-after potential. Therefore, the center point of many research focus is on the study of the cell cycle and apoptosis (Elmore 2007). Therefore, the most anticancer drug worked by apoptosis mechanism. Most signal transduction pathways that play a role in the apoptotic process include intrinsic and extrinsic factors via mitochondrial and apoptotic receptors. Proteins such as p53, Bcl-2, Bax, and caspase, are very influential on the apoptosis process. 7, 8, and 9 (Alenzi et al. 2010). Based on that issue, the next step detected the anticancer mechanism's mode by detecting the apoptosis marker protein included $\mathrm{BCl}-2$, $\mathrm{P} 53$, caspase- 8 and caspase- 9 , to the most toxic genotype. $\mathrm{Bcl}-2$, an anti-apoptosis protein, is an important signal factor of apoptosis that promotes cancer cell growth (Motadi et al. 2020). In this study, the Bcl-2 expression levels of both cancer cell lines decreased on the treatment of $\mathrm{M}$ and TWN extracts. In the HTB-183 cell lines, the $\mathrm{M}$ extract decreased to $40 \%$, while TWN extracts until 54\%. On the other hand, the $\mathrm{M}$ and TWN extract decreased the Bcl-2 expression levels by only $9 \%$ and $23 \%$ of WiDr cell lines. It appears that the HTB-183 cell lines seem more susceptible to both extracts than WiDr. It also looks at the expression of p53. Mutations of p53 are among the most common genetic abnormalities in human cancers (Karak 2018). In this study, the treatment of $\mathrm{M}$ and TWN extracts increased the p53 expression levels at around $100 \%$ on HTB-183 cell lines, while on WiDr cell lines at $66 \%$ and $39 \%$, respectively. The p53 protein plays a major role in apoptosis induction, and it correlated with increasing caspase activity (Motadi et al. 2020). The occurrence of changes in the expression of p53, a suppressor gene, can trigger the growth of cells into cancer cells, so the search for anticancer agents that can suppress p53 expression is a good potential for the search for new cancer drugs (Astirin et al. 2009). Karak (2018) concluded that flavonoid-induced kinase modulation correlated with apoptosis and proliferation of cells and down-regulation of p53 protein. These results supported the statement of Dhutie et al. (2000) that one of the anticancer mechanisms of flavonoids by down-regulation of p53 protein, cell cycle arrest, inhibition of tyrosine kinase, heat shock proteins inhibition, the binding capacity of estrogen receptor, and Ras proteins inhibition. The study of Tulbaghia violacea on some cancer cell lines (HeLa, ME-180, MDA-MBA-231, and MCF-7) showed increased p53 expression until 40\% on HeLa and $33 \%$ on ME180in treated cells (Astirin et al. 2009). The study on methanol extract of flower and stem of H. platytaenium showed that both extracts inhibit T47-D cell lines cancer cell growth but not on MDA-MB-231 cells (Akillilar et al. 2018). From both results, it appears that the extract $\mathrm{M}$ and TWN induced the decrease of expression of $\mathrm{Bcl}-2$, a protein marker of cancer incidence followed by increased expression of protein p53, an apoptosis induction. The study on Cleome droserifolia showed the methanol extract induced antiproliferative of MCF-7 cells line more than $80 \%$ and significantly induced the activity of caspase-8 and caspase-9 (Panicker et al. 2020). Artemisinin act as an anticancer in many mechanisms that induced cell death that induces cell cycle arrest, inhibit angiogenesis and impede cancer metastasis and invasion (Ho et al. 2014; $\mathrm{Ng}$ et al. 2014). Many researchers conclude that artemisinin-induced cancer cell death by apoptosis is a primary mechanism (Wong et al. 2017). It said that artemisinin induced apoptosis by activating the release of both caspase 3/9and caspase- 8 and cytochrome $\mathrm{C}$ or manipulating the expression of anti-apoptotic proteins such as Bcl-2, Bid, and Bak. 


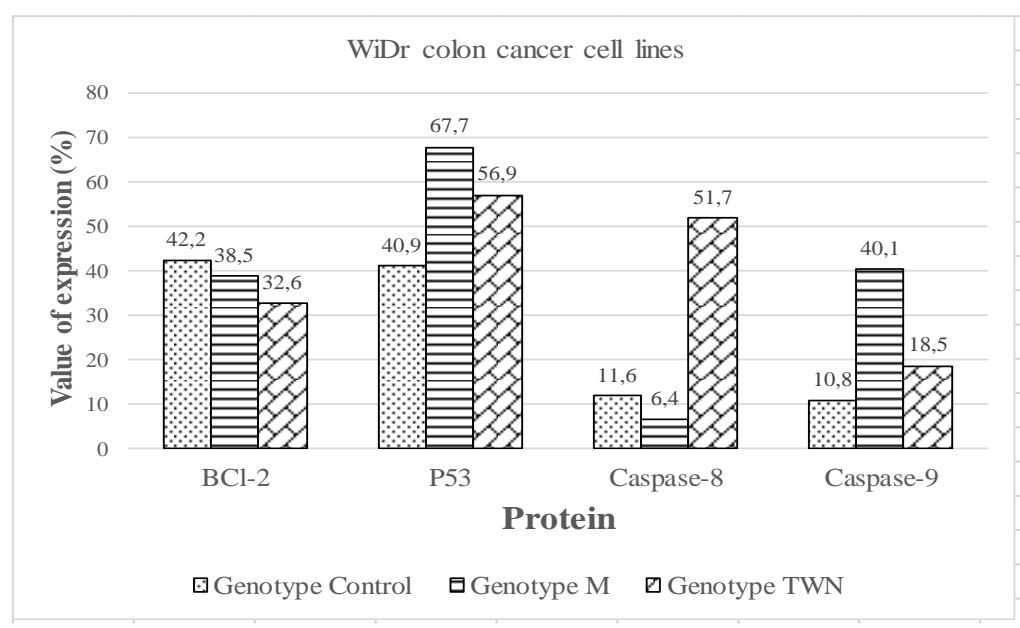

Figure 2. The expression of Bcl-2, p53, caspase-8, and caspase-9 on WiDr colon cancer cell lines treated by ethyl acetate extract of TWN and M, an assay using immunocytochemistry method

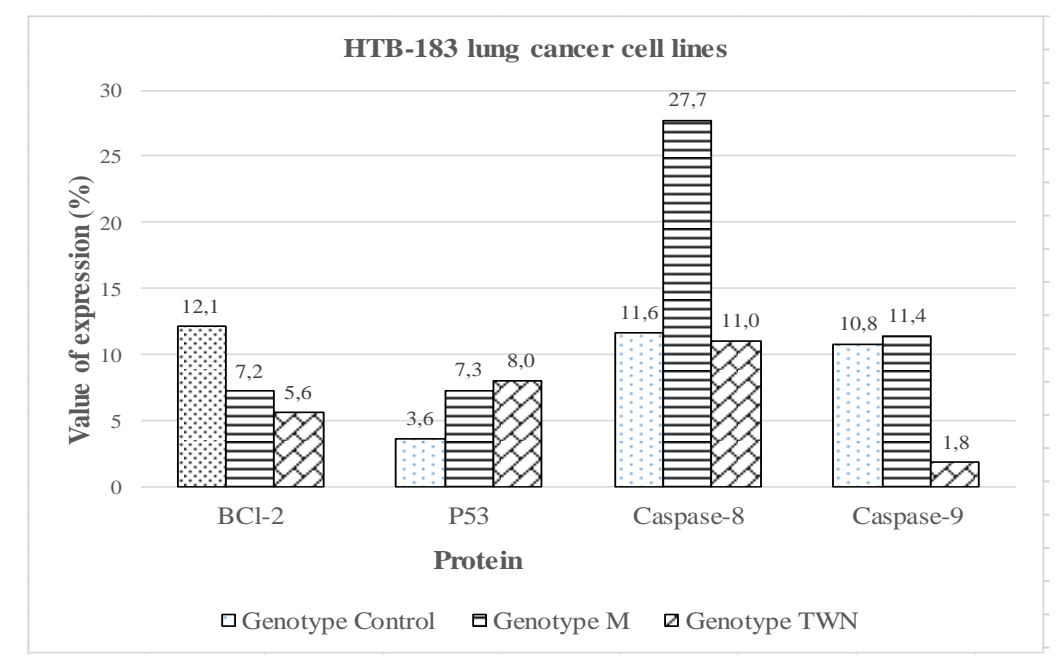

Figure 3. The expression of Bcl-2, p53, caspase-8, and caspase-9 on HTB 183 lung cancer cell lines treated by ethyl acetate extract of TWN and M, an assay using immunocytochemistry method.

In this study, both extracts induced apoptosis cascade in both test cells. In HTB-183 cells, M extracts induced caspase-8 expression up to 1.4 times compared to control without $\mathrm{M}$, while caspase-9 was only 0.6 times. In WiDr cells, $\mathrm{M}$ extracts induced caspase-9 expression up to 2.7 times compared to control without $\mathrm{M}$, whereas TWN extract induced caspase- 8 expression up to 3.5 times but caspase- 9 only 0.7 times. Another researcher reported that artesunate, the artemisinin derivate showed activated caspase-3, -8 , and -9 of MCF-7 cell lines after 24 hours of incubation (Motadi et al. 2020; Jamalzadeh et al. 2017). It supports this study that Artemisia contains bioactive compounds which can be anticancer agents through mechanical induction of apoptosis. This study supports the study that Artemisia contains bioactive compounds that can be anticancer agents through mechanical induction of apoptosis. This study did not assay the caspase-3 expression because if there were caspase- 8 or caspase- 9 expression, then caspase- 3 will be expressed. The TWN extract induced an extrinsic pathway only on both cancer cell lines, while $\mathrm{M}$ extracts induced both intrinsic and extrinsic but only on WiDr cancer cell lines.

Thus, the results confirmed A. cina potential as an anticancer agent, and we could study another cancer cell. Further, the anticancer activity in vivo assay needs to be done.

In conclusion, from all of the above elaboration, it is concluded that the content of quercetin, kaemferol and artemisinin on ethyl acetate extract higher than hexane extract. The ethyl acetate extract of the TWN and M genotypes, with $\mathrm{IC}_{50}$ value, was about $200-300 \mu \mathrm{g} / \mathrm{mL}$, which can inhibit cancer cell growth more substantially than those with $\mathrm{IC}_{50}$ until about $500700 \mu \mathrm{g} / \mathrm{mL}$. The ethyl acetate extract of the TWN induced apoptosis of HTB-183 cell lines through caspase- 8 and caspase-9 pathways, but ethyl acetate extract of the $\mathrm{M}$ induced caspase-9 pathway only. 


\section{ACKNOWLEDGEMENTS}

The author would like to express his deepest gratitude to the Ministry of Research and Technology of the Republic of Indonesia-National Research and Innovation Agency Deputy of Research and Development Strengthening for financial support to implement this research. The number of the contract was SK 135.1 / SPKPDUPT / PR V / 6 / 2020.

\section{REFERENCES}

Abdullah AH, Mohammed AS, Abdullah R, Mirghani MES, Al-Qubaisi M. 2014. Cytotoxic effects of Mangifera indica L. kernel extract on human breast cancer (MCF-7 and MDA-MB-231 cell lines) and bioactive constituents in the crude extract. BMC Compl Altern Med 14:199. DOI: $10.1186 / 1472-6882-14-199$

Akillilar PT, Tuglu YB, Moghaddam NS. 2018. Anticancer, antioxidant properties and phenolic, flavonoid composition of Heracleum platytaenium plant methanolic extracts. Marmara Pharm J 22 (3): 396-404. DOI: 10.12991/jrp.2018.79.

Alenzi FQ, Lotfy M, Wyse RKH. 2010. Swords of cell death: Caspase activation and regulation. Asian Pac J Cancer Prev 11 (2): 271-280.

Arullappan, S. Muhamad S, Zakaria Z. 2013. Cytotoxic activity of the leaves and stem extracts of Hibiscus rosa-sinensis (Malvaceae) against leukaemic cell line (K-562). Trop J Pharm Res 12 (5): $743-$ 746. DOI: 10.4314/tjpr.v12i5.12.

Astirin OP, Harini M, Handajani NS. 2009. The effect of crude extract of Pandanus conoideus Lamb. var. yellow fruit on apoptotic expression of the breast cancer cell line (T47D). Biodiversitas 10 (1): 44-48 DOI: $10.13057 /$ biodiv/d100109.

Boligon AA, Athayde ML. 2014. Importance of HPLC in analysis of plant extracts. Austin Chromatogr1 (3): 1-2.

Carusoa I, Piazb FD, Malafronteb N, Tommasib ND, Aversanoa R, Zottelec CW, Scaranod MT, Carputoa D. 2013. Impact of ploidy change on secondary metabolites and photochemical efficiency in Solanum bulbocastanum. Nat Prod Commun 8 (10): 1387-1392.

Cheng B, Xiong S, Li C, Liang H, Zhao Y, Li J, Shi J, Ou L, Chen Z, Liang P, Liang W, He J. 2020. An annual review of the remarkable advances in lung cancer clinical research in 2019. J Thorac Dis 12 (3): 1056-1069. DOI: 10.21037/jtd.2020.03.11

Choi E, Kim G. 2013. Effect of Artemisia species on cellular proliferation and apoptosis in human breast cancer cells via estrogen receptorrelated pathway. J Tradit Chin Med 33 (5): 658-663. DOI: 10.1016/S0254-6272(14)60038-8.

Dai J, Mumper RJ. 2010. Plant phenolics: Extraction, analysis and their antioxidant and anticancer properties. Molecules 15 (10): 7313-7352. DOI: $10.3390 /$ molecules 15107313

Duthie GG, Duthie SJ, Kyle JAM. 2000. Plant polyphenols in cancer and heart disease: Implications as nutritional antioxidants. Nutr Res Rev 13 (1): 79-106. DOI: 10.1079/095442200108729016.

Do QD, Angkawijaya AE, Tran-Nguyen PL, Huynh LH, Soetaredjo FE, Ismadji S, Ju Y-H. 2014. Effect of extraction solvent on total phenol content, total flavonoid content, and antioxidant activity of Limnophila aromatica. J Food Drug Anal 22 (3): 296-302. DOI: 10.1016/j.jfda.2013.11.001

Elmore S. 2007. Apoptosis: A review of programmed cell death. Toxicol Pathol 35 (4): 495-516. DOI: 10.1080/01926230701320337

Gao 1, Wei N, Yang G, Zhang Z, Liu G, Cai C. 2019. Ethnomedicine study on traditional medicinal plants in the Wuliang Mountains of Jingdong, Yunnan, China. J Ethnobiol Ethnomed 15: 41-60. DOI: 10.1186/s13002-019-0316-1.

Herawati MM, Purwantoro A, Soegihardjo CJ. 2003. Produksi artemisinin melalui kultur pucuk Artemisia cina Berg ex Poljakov dengan perlakuan sukrosa dan ekstrak khamir. [Tesis]. Universitas Gadjah Mada, Yogyakarta. [Indonesian]

Ho WE, Peh HY, Chan TK, Wong WSF. 2014. Artemisinins: Pharmacological actions beyond antimalarial. Pharmacol Ther 42 (1): 126-139. DOI: 10.1016/j.pharmthera.2013.12.001.
Hussain A, Hayat MQ, Sahreen S, Ain Q, Bokhari SAI. 2017. Pharmacological promises of genus Artemisia (Asteraceae): A review. Proc Pak Academic Sci: B. Life and Environ Sci 54 (4): 265-287.

Jakovljević MR, Grujičić D, Živanović M, Stanković M, Ćirić A, Djurdjević P, Todorović Z, Živančević-Simonović Z, Mihaljević O, Milošević-Djordjević O. 2019. Ethyl acetate extracts of two Artemisia species: Analyses of phenolic profile and anticancer activities against SW-480 colon cancer cells. Nat Prod Commun 14 (5): 1-9. DOI: 10.1177/1934578X19843011.

Jamalzadeh J, Ghafoori H, Aghamaali M, Sariri R. 2017. Induction of apoptosis in human breast cancer MCF-7 Cells by a semi-synthetic derivative of Artemisinin: A caspase-related mechanism. Iranian J Biotech 15 (3): 157-165. DOI: 10.15171/ijb.1567.

Kashani HH, Hoseini ES, Nikzad H, Aarabi MH. 2012. Pharmacological properties of medicinal herbs by the focus on secondary metabolites. Life Sci J 9 (1): 509-520.

Karak P. 2018. Biological activities of flavonoids: An overview. Int J Pharm Sci Res 10 (4): 1567-1574.

Kasmiyati S, Kristiani EBE, Herawati MM. 2020. Effect of induced polyploidy on plant growth, chlorophyll and flavonoid content of Artemisia cina. Biosaintifika 12 (1): 90-96. DOI: 10.15294/biosaintifika.v12i1.22548.

Koul B, Taak P, Kumar A, Khatri T, Sanyal I. 2017. The Artemisia genus: A review on traditional uses, phytochemical constituents, pharmacological properties and germplasm conservation. J Glycomics Lipidomics 7 (1): 142-148. DOI: 10.4172/2153-0637.1000142.

Kristiani EBE, Nugroho LH, Moeljopawiro S, Widyarini S. 2016. Characterisation of volatile compounds of Albertisia papuana Becc root extracts and cytotoxic activity in breast cancer cell line T47D. Trop J Pharm Res15 (5): 959-964. DOI: 10.4314/tjpr.v15i5.9.

Kursat M, Emre I, Yilma O, Civele S, Demir E. Turkoglu I. 2015. Phytochemical contents of five artemisia species. Not Sci Biol 7 (4): 495-499. DOI: $10.15835 / \mathrm{nsb} 749683$.

Lee S, Peterson CJ, Coats JR. 2003. Fumigation toxicity of monoterpenoids to several stored product insects. J Stored Prod Res 39 (1): 77-85. DOI: 10.1016/S0022-474X(02)00020-6.

Mahendra JAIN, Mishra SH. Albert S. Kapadia R. 2011. Standardization of Feronia limonia L. leaves by HPLC, HPTLC, physicochemical and histological parameters. Boletín Latinoamericano y del Caribe de Plantas Medicinales y Aromáticas 10 (6): 525-535. [Spanish]

Martin M, Guiochon G. 2005. Effects of high pressure in liquid chromatography. J Chromatogr A. 1090 (1-2): 16-38. DOI: 10.1016/j.chroma.2005.06.005.

Meerloo JV, Kaspers GJL, Cloos J. 2011. Cell Sensitivity Assays: The MTT Assay. In: Ian A. Cree (ed.), Cancer Cell Culture: Methods and Protocols, Second Edition, Methods in Molecular Biology. Springer Science+Business Media, LLC., New York.

Mojarraba M, Lagzian M-S, Emamic SA, Asilic J, Tayarani-Najaranb Z. 2013. In vitro antiproliferative and apoptotic activity of different fractions of Artemisia armeniaca. Rev Bras Farmacogn 23: 783-788. DOI: 10.1590/S0102-695X2013000500010.

Motadi LR, Choene MS, Mthembu NN. 2020. Anticancer properties of Tulbaghia violacea regulate the expression of p53-dependent mechanisms in cancer cell lines. Sci Rep 10: 12924. DOI: 10.1038/s41598-020-69722-4

Mukazayire MJ, Bigendako MJ, Ingabire G, Nyetera P, Stévigny C, Duez P. 2009. Comparison of artemisinin levels in Artemisia annua L. cultivated at three distinct geographic regions in Rwanda. Planta Med 75: PJ189. DOI: 10.1055/s-0029-1234994.

Ng DSW, Liao W, Tan WSD, Chan TK, Loh XY, Wong WSF. 2014. Antimalarial drug artesunate protects against cigarette smoke-induced lung injury in mice. Phytomedicine 21 (12): 1638-1644. DOI: 10.1016/j.phymed.2014.07.018.

Ngo TV, Scarlett CJ, Bowyer MC, Ngo PD, Vuong QV. 2017. Impact of different extraction solvents on bioactive compounds and antioxidant capacity from the root of Salacia chinensis L. J Food Quality 2017 (1): 1-8. DOI:10.1155/2017/9305047.

Naboulsi I, Aboulmouhajir A, Kouisni L, Bekkaoui F, Yasri A. 2018 Plants extracts and secondary metabolites, their extraction methods, and their use in agriculture to control crop stresses and improve productivity: A review. Academia J Med Plants 6 (8): 223-240. DOI: 10.15413/ajmp.2018.0139.

Numonov S, Sharopov F, Salimov A, Sukhrobov P, Atolikshoeva S, Safarzoda R, Habasi M, Aisa HA. 2019. Assessment of artemisinin contents in selected Artemisia species from Tajikistan (Central Asia). Medicines 6 (23): 1-10. DOI:10.3390/medicines6010023 . 
Piana M, Zadra M, de Brum TF, Boligon AA, Gonçalves AF, da Cruz RC, de Freitas RB, do Canto GS, Athayde ML. 2013. Analysis of rutin in the extract and gel of Viola tricolor. J Chromatogr Sci 51 (5): 406411. DOI: $10.1093 /$ chromsci/bms 155 .

Pagare S, Bhatia M, Tripathi N, Pagare S, Bansal YK. 2015. Secondary metabolites of plants and their role: Overview. Curr Trends Biotechnol Pharm 9 (3): 293-304.

Panicker NG, Balhamar SOMS, Akhlaq S, Qureshi MM, Rehman NU, AlHarrasi A, Hussain J, Mustafa F. 2020. Organic extracts Cleome droserifolia exhibit effective caspase-dependent anticancer activity. BMC Compl Med Ther 20 (1): 74. DOI: 10.1186/s12906-020-2858-0.

Piao GC, Li YX, Yuan HD, Jin GZ. 2012. Cytotoxic fraction from Artemisia sacrorum Ledeb. against three human cancer cell lines and separation and identification of its compounds. Nat Prod Res 26: 1483-1491. DOI: 10.1080/14786419.2011.565473.

Poojan S, Kim H-S, Yoon J-W, Sim HW, Hong K-M. 2018 Determination of protein expression level in cultured cells by immunocytochemistry on paraffin-embedded cell blocks. J Vis Exp 135: 57369. DOI: 10.3791/57369.

Rabe SZT, Mahmoudi M, Ahi A, Emami SA. 2011. Antiproliferative effects of extracts from Iranian Artemisia species on cancer cell lines. Pharm Biol 49 (9): 962-969. DOI: 10.3109/13880209.2011.559251.

Siegel RL, Miller KD, Sauer AG, Fedewa SA, Butterly LF, Anderson JC, Cercek A, Smith RA, Jemal A. Colorectal cancer statistics, 2020. CA Cancer J Clin 70 (3): 145-164. DOI: 10.3322/caac.21601.

Sholikhah EN. 2016. Indonesian medicinal plants as sources of secondary metabolites for pharmaceutical industry. J Med Sci 48 (4): 226-239. DOI: 10.19106/JMedSci004804201606.

Shree TJ, Poompavai S, Begum SMFM, Gowri SV, Hemalatha S, Sieni E, Sundararajan R. 2019. Cancer-fighting phytochemicals: another look. A review. J Nanomed Biotherapeutic Discov 8 (162): 1-6. DOI: 10.4172/2155-983X.1000162.

Susidarti RA, Jenie RI, Ikawati M, Putri DDP, Meiyanto E. 2014. Cytotoxic activity and apoptosis induction of 8 hydroxyisocapnolactone $2^{\prime}, 3^{\prime}-$ diol and its combination with
Doxorubicin on MCF-7 and T47D cells. J Appl Pharm Sci 4 (6): 8997. DOI: 10.7324/JAPS.2014.40614.

Tayarani-Najaran Z, Hajian Z, Mojarra M, Emami SA. 2014. Cytotoxic and apoptotic effects of extracts of Artemisia ciniformis Krasch. \& Popov ex Poljakov on K562 and HL-60 cell lines. Asian Pac J Cancer Prev 15 (17): 7055-7059. DOI: 10.7314/APJCP.2014.15.17.7055.

Tokuşoğlu Ö, Ünal MK, Yıldırım Z. 2003. HPLC-UV and GC-MS characterization of the flavonol aglycons quercetin, kaempferol, and myricetin in tomato pastes and other tomato-based products. Acta Chromatographica 13 (13): 196-207.

Truong D-H, Nguyen DH, Ta NTA, Bui AV, Do TH, Nguyen HC. 2019. Evaluation of the use of different solvents for phytochemical constituents, antioxidants, and in vitro anti-inflammatory activities of Severinia buxifolia. J Food Quality 2019 (1): 1-9. DOI: $10.1155 / 2019 / 8178294$.

Tuzlaci E, Senkardes I. 2011. Turkish folk medicinal plants, X: Ürgüp (Nevüehir). Marmara Pharm J. 2011; 15: 58-68.

WHO. Cancer. https://www.who.int/news-room/fact-sheets/detail/cancer, (accessed on 6 December 2020)

Wang H, Khorb TO, Shub L, Sub Z, Fuentesb F, Leeb JH, Kong A-NT. 2012. Plants against cancer: A review on natural phytochemicals in preventing and treating cancers and their druggability. Anticancer Agents Med Chem 12 (10): 1281-1305.

Wong YK, Xu C, Kalesh KA, Yingke HY, Lin Q, Wong WSF, Shen HM, Wang J. 2017. Artemisinin as an anticancer drug: Recent advances in target profiling and mechanisms of action. Med Res Rev 37 (6): 14921517 DOI: $10.1002 / \mathrm{med} .21446$.

Yuan H, Lu X, Ma Q, Li D, Xu G, Piao G. 2016. Flavonoids from Artemisia sacrorum Ledeb and their cytotoxic activities against human cancer cell lines. Exp Ther Med 12 (3): 1873-1878. DOI: 10.3892/etm.2016.3556.

Zhang Q-W, Lin L-G, Ye W-C. 2018. Techniques for extraction and isolation of natural products: A comprehensive review. Chinese Med 13: 20. DOI: 10.1186/s13020-018-0177-x. 